\title{
Transport of biogenes in the Szeszupa fluvial-limnic system in the Suwalski Landscape Park
}

\author{
Elżbieta Jekatierynczuk-Rudczyk \\ Department of Hydrobiology, Institute of Biology, University of Białystok, Świerkowa 20B, 15-950 Białystok, Poland, \\ e-mail: rudczyk@uwb.edu.pl
}

\begin{abstract}
Transport of biogenic matter along the course of the Szeszupa River in the Suwalski Landscape Park (SLP) occurs in accordance with the river continuum concept. Only TP concentration decreases along the river's course. TP and TOC concentrations classify the Szeszupa River to the moderate ecological state. The ecological state of three lakes (Linówek, Pogorzałek, and Perty) in the Szeszupa River catchment was estimated as very good. The remaining lakes, due to high TP concentrations, belong to the moderate state. The management of the catchment affects the amount of biogenic matter supplied to the Szeszupa River. The highest proportion of forests in the Jaczniówka River catchment clearly results in a decrease in the amount of biogenes in the river. The remaining partial catchments, with a higher proportion of arable land, meadows, and pastures, provide higher amounts of bioelements. The loads of bioelements stored in lakes in the summer period are determined by the size of the lakes (surface area of a lake and volume of water accumulated in the lake basin). This directly suggests a lack of anthropogenic activity in the catchments or the very slight effect of it on the lakes' ecological and trophic state.
\end{abstract}

Key words: water quality, biophilic elements, ecological state, trophic index

\section{Introduction}

Biophilic elements (nutrients, bioelements, biogenes) are necessary for life, and their content in the environment can limit the biological activity of ecosystems. In surface waters, bioelements affect processes such as primary production, microbiological decomposition of organic matter, and stimulation of growth of autotrophic organisms. Transport of biogenes in fluvial-limnic systems is a very complex process. A number of authors evidenced the accumulative role of lakes in relation to biogenes (HillbrichtIlkowska 1999, 2005; Lossow et al. 2006; Bogdanowicz and Cysewski 2008; Maślanka and Jańczak 2010). In the hydrometeorological conditions of the temperate zone, the role is variable throughout the year. In the summer period, when the shoreline of lakes is overgrown with macrophytes, the load of biogenes can be accumulated in plants and bottom sediments of the littoral zone. The objective of the hydrological-hydrochemical study on the Szeszupa River catchment in the Suwalski Landscape Park (SLP) was as follows:
- to analyse the concentrations and loads of biogenes in the Szeszupa fluvial-limnic system,

- to evidence the effect of the catchment management on the concentration and loads of biogenes in waters of the Szeszupa River and its tributaries,

- to determine the role of lakes in the accumulation of biogene elements.

\section{Methods}

The hydrological and hydrochemical study in the catchment of the Upper Szeszupa River in the Suwalski Landscape Park was conducted in July and August 2009-2010. Changes in the transport of biogenes along the course of the Szeszupa River were estimated based on 9 sites distributed along the course of the river (Fig. 1). In July 2009, the hydrochemical assessment of lakes in the Szeszupa River catchment was conducted (Fig. 1). Lake water for analyses was sampled from the epi-, meta-, and hypolimnion by means of the Bernatowicz's apparatus. In the field, the Secchi visibility, water reaction $(\mathrm{pH})$, water temperature, electrolytic conductivity 


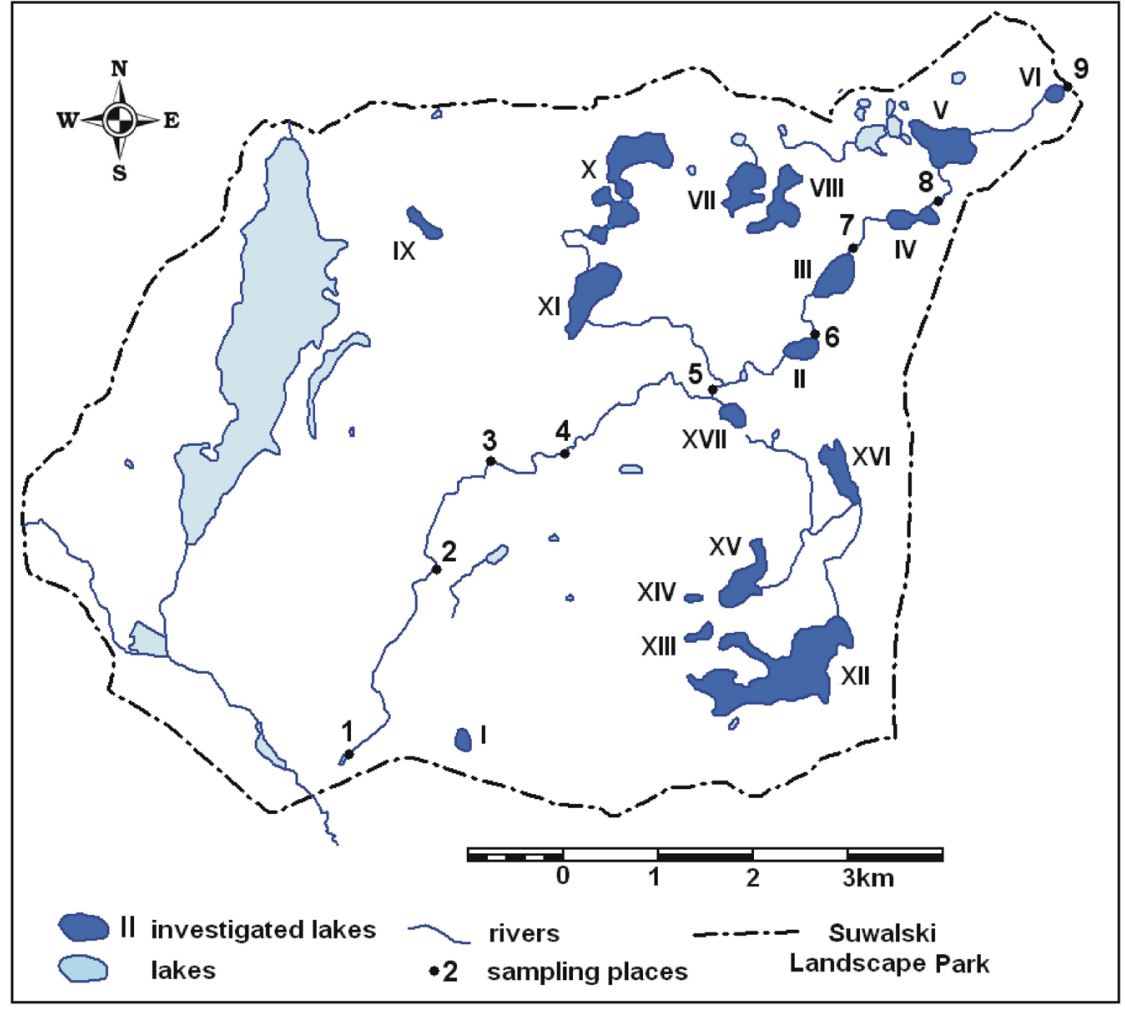

Fig. 1. Study area: 1-9 - sampling points (rivers), I-XVII - sampling points (lakes)

(EC), and saturation of water with oxygen were measured with the application of the Hach Lange sonde. The discharge rate of the Szeszupa River and its tributaries was measured by means of an electromagnetic sensor by OTT. Measurements of the discharge rate of the Szeszupa River were conducted at the sites of sampling water for chemical analyses. The discharge rate of the Szurpiłówka River was determined below Lake Udziejek, and that of the Jaczniówka River below Lake Kamenduł (Fig.1, Table 1).

At the laboratory of the Department of Hydrobiology of the University of Białystok, the following concentrations were determined: Kiejdahl nitrogen by means of an analyser by Tecator; ammonia nitrogen $\left(\mathrm{N}-\mathrm{NH}_{4}^{+}\right)$- by means of the indophenol method; nitrate nitrogen $\left(\mathrm{N}-\mathrm{NO}_{3}{ }^{-}\right)$- by means of the reduction method with $\mathrm{z}$ naphthylethylenediamine; nitrite nitrogen $\left(\mathrm{N}-\mathrm{NO}_{2}^{-}\right)$- by the reduction method with naphthylethylenediamine; soluble reactive phosphorus (SRP) - by means of the molybdate method; dissolved phosphorus (DP) and total phosphorus (TP) by means of the molybdate method after previous mineralisation with UV radiation; total organic carbon (TOC) and dissolved organic carbon (DOC) - by means of a Schimadzu TOC - 5050 apparatus, following methods proposed by Hermanowicz et al. 1999. The concentrations of the remaining forms of biogene elements were calculated based on the previous analyses: mineral nitrogen $(\mathrm{TMN})=\left(\mathrm{N}-\mathrm{NH}_{4}^{+}\right)+\left(\mathrm{N}-\mathrm{NO}_{3}^{-}\right)+\left(\mathrm{N}-\mathrm{NO}_{2}{ }^{-}\right)$, organic nitrogen $(\mathrm{TON})=\left(\right.$ Kiejdahl nitrogen $\left.-\mathrm{N}^{-} \mathrm{NH}_{4}^{+}\right)$, total

Table 1. Morphometric parameters of the rivers in the Szeszupa catchment in SLP

\begin{tabular}{lcccc}
\hline \multirow{2}{*}{ River } & Length of the river & Average rate of flow & Tortuosity & Slope of the river \\
\cline { 2 - 5 } & {$[\mathrm{km}]$} & {$\left[\mathrm{dm}^{3} \mathrm{~s}^{-1}\right]$} & 1.4 & 3.7 \\
\hline Szeszupa River (below Lake Postawelek) & 13.95 & 208 & 3.0 & 5.1 \\
Szurpiłówka River (below Lake Udziejek) & 6.00 & 78 & 3.1 & 1.6 \\
Jaczniówka River (below Lake Kamenduł) & 5.00 & 55 & \\
\hline
\end{tabular}


nitrogen $(\mathrm{TN})=(\mathrm{TMN}+\mathrm{TON})$, and particle organic carbon $(\mathrm{POC})=$ TOC - DOC .

Mean concentration of biogenes in lakes was calculated based on samples from the epi-, meta-, and hypolimnion. If more than one study site was located within a lake, the mean was calculated from all the sites. Mean concentration of biogenes in rivers was calculated based on measurements conducted in July and August 2009-2010. The Trophic Status Index (TSI) was calculated for the lakes studied following Carlson (Carlson 1977).

The analysis of transport of biogenes in the Szeszupa fluvial-limnic system was conducted based on distinguishing four partial catchments: the source catchment of the Szeszupa River with an area of 15.9 $\mathrm{km}^{2}$ closed at the mouth of the Szurpiłówka River, the Jaczniówka River catchment with an area of $16.6 \mathrm{~km}^{2}$, the Szurpiłówka River catchment of $16.1 \mathrm{~km}^{2}$, and the direct catchment of the Szeszupa River below the mouth of the Szurpiłówka River. The surface area of the partial catchments was calculated based on the watersheds marked on topographic maps at the scale 1:25000.

The statistical analysis was conducted with the application of Statgraphics 5.0 software.

\section{Study area}

The Szeszupa River is a left-bank tributary of the Neman River. It flows through territories of three countries: Poland, Russia, and Lithuania. Its length amounts to $298 \mathrm{~km}$, whereas the "Polish" section has a length of $27 \mathrm{~km}$. The length of the fragment subject to the study, flowing through the Suwalski Landscape Park, amounts to $13.95 \mathrm{~km}$. The springs of the Szeszupa River are located in riparian forests near Turtul. From there, the river flows in the NE direction in an extensive depression called the Szeszupa River Depression (Bajkiewicz-Grabowska 1994). In the SLP, tributaries of the Szeszupa River are the Jaczniówka and Szurpiłówka Rivers (Table 1). In physical-geographical terms, the Szeszupa River catchment belongs to the Lithuanian Lakeland Macroregion, East Suwałki Lakeland Mesoregion (Kondracki 1998).

In the SLP, the Szeszupa River flows through five shallow lakes: Gulbin, Okrągłe, Krajwelek, Przechodnie, and Postawelek. The Szurpiłówka River, a rightbank tributary of the Szeszupa River with a length of $6 \mathrm{~km}$, drains an area of $16.36 \mathrm{~km}^{2}$. Flowing in the northern direction, it drains Lakes Kopane, Udziejek,
Szurpiły, Jeglówek, and Jeglóweczek. The Jaczniówka River, a left-bank tributary of the Szeszupa River with a length of $5 \mathrm{~km}$, drains an area of $19.64 \mathrm{~km}^{2}$ (Table 1) and flows through Lakes Jaczno and Kamenduł (Bajkiewicz-Grabowska 1994).

The discharge rate during the study period along the course of the Szeszupa River varied from $18.6 \mathrm{~s}^{-1}$ in the source section to $402.81 \mathrm{~s} \mathrm{~s}^{-1}$ along the 14 $\mathrm{km}$ course of the river. The Szurpiłówka River was distinguished by a higher mean discharge rate $\left(78 \mathrm{l} \mathrm{s}^{-1}\right)$ and higher inclination $(5.1 \%$ ) than the Jaczniówka River (Table 1). The river development indices in the Szurpiłówka and Jaczniówka Rivers are similar, and exceed the development index of the Szeszupa River more than twice (Table 1).

The largest lake in the Szeszupa River catchment in the SLP is Lake Szurpiły with an area of 80.9 ha (Table 2). Almost half of the lakes in the area discussed are small lakes of less than 10 ha. The highest located lake is Lake Linówek - 199.7 m a.s.l.; the lowest lake is Lake Postawelek - 145.7 m a.s.l. The lowest volume of water is accumulated in Lakes Jeglóweczek and Linówek: $0.061 \mathrm{hm}^{3}$ and $0.070 \mathrm{hm}^{3}$, respectively. Lakes Szurpiły $\left(8.2 \mathrm{hm}^{3}\right)$ and Jaczno $\left(4.8 \mathrm{hm}^{3}\right)$ have the highest volume. According to the fishery classification, only Lake Linówek is a very shallow lake. The group of shallow lakes includes 8 lakes. The remaining lakes are deep and very deep (Table 2). The lowest proportion of forests $(<20 \%)$ occurs in the catchments of Lakes Gulbin, Okrągłe, Krajwelek, Postawelek, Kopane, Udziejek, and Szurpiły. In the catchments of Lakes Pogorzałek, Jaczno, Kameduł, and Jeglóweczek, the forest cover exceeds $50 \%$, and reaches $74 \%$ in the direct catchment of Lake Pogorzałek. The source part of the Szeszupa River catchment is dominated by cultivated land. Forests occupy only $30 \%$ of the area (Fig. 2). In the Szurpiłówka River catchment, forests constitute approximately $20 \%$ of the area. The Jaczniówka River catchment drains an agricultural-forest area dominated by forests (approximately $65 \%$ of the area). The direct catchment of the Szeszupa River below the mouth of the Szurpiłówka River is agriculturalforest in character. It is dominated by cultivated land (approximately 60\%). Forests occupy approximately $20 \%$ of the area. The land management and geological structure influence the degree of threat to groundwaters. Based on the Hydrogeological Map of Poland (PIG 2009), a moderate, low, and very low degree of threat to groundwaters was determined in the source part of the Szeszupa River catchment. The moderate 
Table 2. Morphometrical and hydrological characteristics of the lakes and Trophic Status Index in the Szeszupa catchment (roman numbers compatible with numbers in Figure 1; hydrological type of the lake: c - closed lake, f - flow lake, o - lake without outflow) (Bajkiewicz-Grabowska 1994; Jańczak 1999)

\begin{tabular}{|c|c|c|c|c|c|c|}
\hline No. & Lake & Surface of the lake & Average depth (maximum depth) & Volume of water & Hydrological type of lake & TSI \\
\hline & & [ha] & {$[\mathrm{m}]$} & {$\left[\mathrm{hm}^{3}\right]$} & & \\
\hline \multicolumn{7}{|c|}{ Szeszupa direct catchment } \\
\hline I. & Linówek & $2.6^{*}$ & $3(5.6)$ & 0.070 & c & 51 \\
\hline II. & Gulbin & 8.5 & $5.6(9.4)$ & 0.266 & $f$ & 57 \\
\hline III. & Okrągłe & 16.5 & $4.6(8.0)$ & 0.716 & f & 61 \\
\hline IV. & Krajwelek & 10 & $3.3(6.0)$ & 0.474 & f & 62 \\
\hline V. & Przechodnie & 26.8 & $3.3(6.3)$ & 0.849 & f & 60 \\
\hline VI. & Postawelek & 4.2 & $2.6(5.4)$ & 0.092 & $f$ & 58 \\
\hline VII. & Kojle & 19.3 & $10.9(27.5)$ & 1.755 & $d$ & 54 \\
\hline VIII. & Perty & 21.6 & $6(31.0)$ & 1.019 & 0 & 40 \\
\hline \multicolumn{7}{|c|}{ Jaczniówka catchment } \\
\hline IX. & Pogorzałek & 6.5 & $3.5(8)$ & 0.111 & c & 66 \\
\hline $\mathrm{X}$ & Jaczno & 41.8 & $11.7(29.6)$ & 4.797 & $f$ & 53 \\
\hline XI. & Kameduł & 27.2 & $6.8(24.5)$ & 1.731 & $f$ & 56 \\
\hline \multicolumn{7}{|c|}{ Szurpiłówka catchment } \\
\hline XII. & Szurpiły & 80.9 & $10.0(46.2)$ & 8.168 & $f$ & 54 \\
\hline XIII. & Kluczysko & 3.6 & $3.5(13.6)$ & 0.212 & 0 & 55 \\
\hline XIV. & Jeglóweczek & 1.7 & $2.9(6)$ & 0.061 & 0 & 56 \\
\hline $\mathrm{XV}$. & Jeglówek & 20.6 & $7.5(18.1)$ & 1.444 & $f$ & 44 \\
\hline XVI. & Kopane & 17 & $7.3(17.4)$ & 1.059 & $f$ & 64 \\
\hline XVII. & Udziejek & 7.4 & $3.8(7.2)$ & 0.229 & $f$ & 63 \\
\hline
\end{tabular}

* - without peat

Fig. 2. Land use in the catchment of the Upper Szeszupa River (own study)

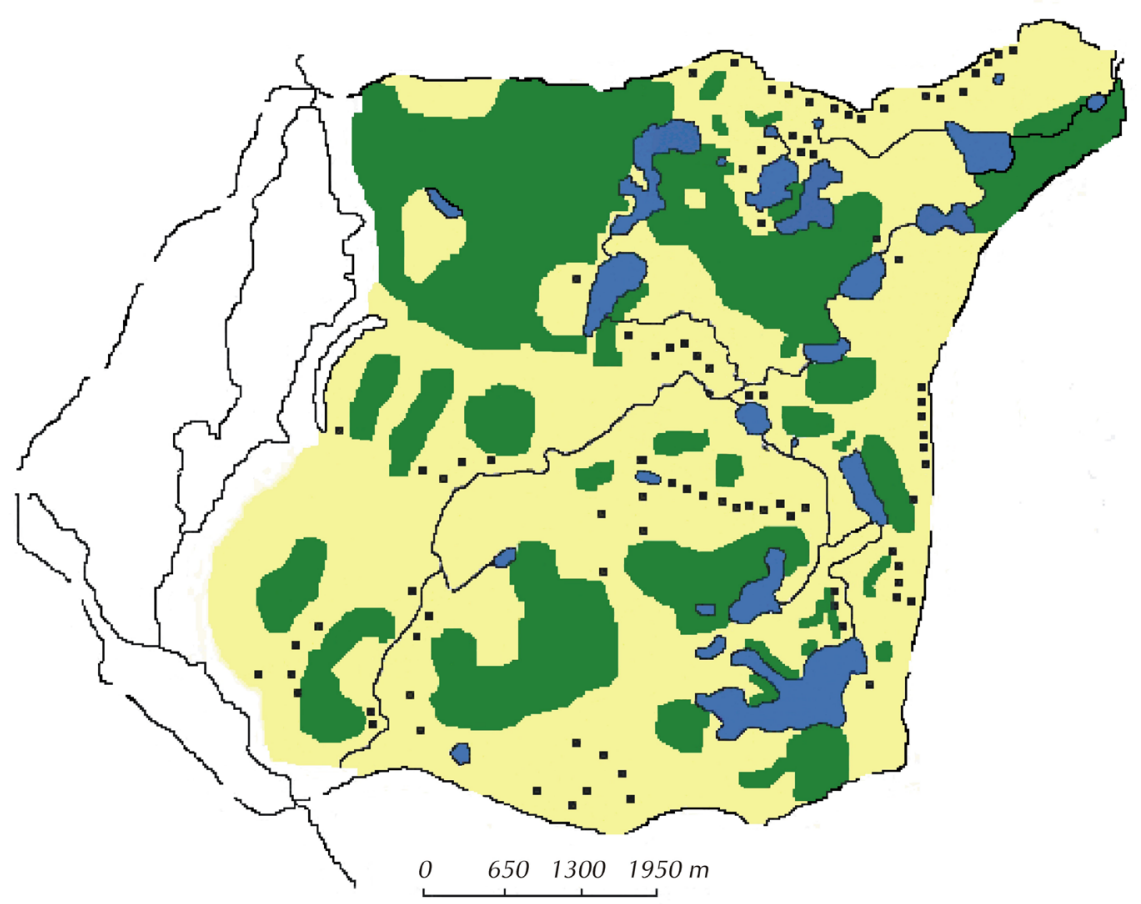

$65013001950 \mathrm{~m}$

Forest $\square$-Agricultural land

- Lakes

-Built-up areas 
degree of threat to groundwaters refers to the entire Szeszupa River Valley in the SLP and the direct catchment of Lakes Jaczno and Kamenduł. In the remaining area, a low and very low degree of threat to groundwaters was determined.

Inflow of groundwaters plays a considerable role in water circulation of the area. In the Suwalski Landscape Park, numerous natural outflows of groundwaters occur. Earlier studies reveal the existence of more than 100 springs, most of which are located in the Szeszupa River catchment (Nowakowski 1976; Bajkiewicz-Grabowska 1994). Studies conducted in the years 2008-2010 in SLP suggest a considerably lower number of natural outflows of groundwaters functioning in the summer period in the area discussed.

\section{Results}

In the summer period, water temperature in the Szeszupa River in the source section did not exceed $20^{\circ} \mathrm{C}$, and in the lake section, it varied from 25 to $26^{\circ} \mathrm{C}$. The multiple comparison test confirmed the statistical significance of the difference in temperature in both sections of the river. Apart from water temperature in the river, statistical significance of differences was determined for water reaction, water conductivity, concentrations of calcium and magnesium, nitrite and nitrate nitrogen, dissolved phosphorus, and silicon compounds. Much higher water conductivity occurring in the source section $\left(530 \mu \mathrm{S} \mathrm{cm}^{-1}\right)$ than the lake section $\left(443 \mu \mathrm{S} \mathrm{cm}^{-1}\right)$ entailed the variability of $\mathrm{Ca}(81$ and $106 \mathrm{mg} \mathrm{dm}^{-3}$ on average) and $\mathrm{Mg}$ concentrations (8.4 and $14.5 \mathrm{mg} \mathrm{dm}^{-3}$ ). In the summer period, waters of the Szeszupa River and its tributaries were well oxygenated (84-105\%). Mean $\mathrm{N}_{-} \mathrm{NH}_{4}$ concentration in the water of the Szeszupa River in summer 20092010 amounted to $353 \mu \mathrm{g} \mathrm{dm}{ }^{-3}$. The variability of this parameter along the river course reached 30\% (Fig.
3A). Nitrate nitrogen constituted almost $40 \%$ of total nitrogen in the cross-section closing the catchment studied. Somewhat higher variability along the river course distinguished the remaining forms of mineral nitrogen $\mathrm{N}-\mathrm{NO}_{2}-\mathrm{CV}=58 \%$ and $\mathrm{N}-\mathrm{NO}_{3}-\mathrm{CV}=59 \%$. In the source section, the concentration of those forms of nitrogen was considerably higher than in the lake section (Fig. 3A), and the calculated mean concentration in both sections differed significantly (multiple comparison test). The dominant form of nitrogen in the water of the Szeszupa River was TON. In the lake section, its content exceeded $2 \mathrm{mg} \mathrm{dm}^{-3}$, which constituted almost 90\% TN (Fig. 3B). High concentration variation occurred in the case of SRP $(\mathrm{CV}=97 \%)$. In the lake section, it grew to $180 \mu \mathrm{g} \mathrm{dm}^{-3}$. In the lake section, the proportion of PP in the phosphorus structure was higher, and the percentage content of this form of phosphorus reached $50 \%$. The content of the forms of organic carbon analysed decreased along the river course. In the lake section, POC content increased considerably (Fig. 3C).

The highest amounts of $\mathrm{N}-\mathrm{NO}_{2}$ and $\mathrm{N}-\mathrm{NO}_{3}$ inflow to the waters of the Szeszupa River from the source catchment $\left(0.07 \mathrm{mg} \mathrm{s}^{-1} \mathrm{~km}^{-2}\right.$ and $1.7 \mathrm{mg} \mathrm{s}^{-1}$ $\mathrm{km}^{-2}$, respectively), and the lowest amounts from the Jaczniówka River catchment $\left(0.01 \mathrm{mg} \mathrm{s}^{-1} \mathrm{~km}^{-2}\right.$ and 0.1 $\mathrm{mg} \mathrm{s}^{-1} \mathrm{~km}^{-2}$, respectively) (Table 3 ). The most N-NH is supplied from the direct catchment of the Szeszupa River $\left(3.8 \mathrm{mg} \mathrm{s}^{-1} \mathrm{~km}^{-2}\right)$, and the least from the Jaczniówka River catchment $\left(0.8 \mathrm{mg} \mathrm{s}^{-1} \mathrm{~km}^{-2}\right)$. The most intensive transport of TN occurs in the direct catchment of the Szeszupa River, and amounts to almost 21 $\mathrm{mg} \mathrm{s}^{-1} \mathrm{~km}^{-2}$. In the Szurpiłówka River catchment, the amount of TN from each $\mathrm{km}^{2}$ of the catchment is almost 5 times lower (Table 3 ). The highest contribution in the transport of phosphorus from the catchment to the waters of the Szeszupa River occurs in the catchment of the source section and the Szeszupa River catchment below the mouth of the Szurpiłówka Riv-

Table 3. Transport of nutrients $\left(\mathrm{mg} \mathrm{s}^{-1} \mathrm{~km}^{-2}\right)$ of the partitive Szeszupa catchment in the summer of 2009-2010

\begin{tabular}{|c|c|c|c|c|c|c|c|c|c|c|c|c|c|}
\hline \multirow{2}{*}{ Catchment } & \multicolumn{5}{|c|}{ Nitrogen compounds } & \multicolumn{5}{|c|}{ Phosphorus compounds } & \multicolumn{3}{|c|}{ Organic carbon compounds } \\
\hline & $\mathrm{N}-\mathrm{NO}_{2}^{-}$ & $\mathrm{N}-\mathrm{NO}_{3}^{-}$ & $\mathrm{N}-\mathrm{NH}_{4}^{-}$ & TON & $\mathrm{TN}$ & SRP & ORP & DP & PP & TP & $\mathrm{DOC}$ & POC & TOC \\
\hline Headwaters of Szeszupa catchment & 0.07 & 1.7 & 2.4 & 8.9 & 13.0 & 0.3 & 2.8 & 3.1 & 2.3 & 5.4 & 88.7 & 13.6 & 102.2 \\
\hline Jaczniówka catchment & 0.01 & 0.1 & 0.8 & 5.0 & 6.0 & 0.2 & 0.05 & 0.2 & 0.2 & 0.4 & 24.9 & 3.3 & 28.3 \\
\hline Szurpiłówka catchment & 0.02 & 0.2 & 1.7 & 1.7 & 3.6 & 0.2 & 0.5 & 0.7 & 0.1 & 0.8 & 70.6 & 4.5 & 75 \\
\hline Szeszupa direct catchment & 0.04 & 0.8 & 3.8 & 16.1 & 20.9 & 1.2 & 2 & 3.2 & 3.1 & 6.4 & 161.2 & 59.6 & 220.8 \\
\hline
\end{tabular}




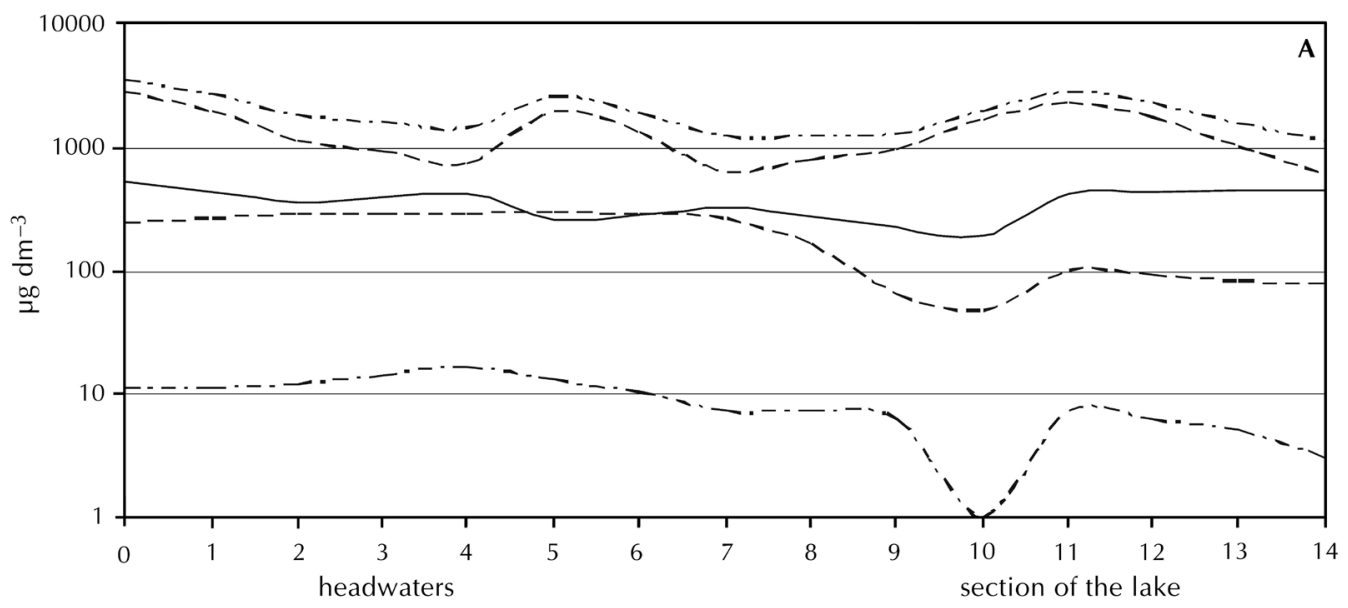

kilometres of the river course

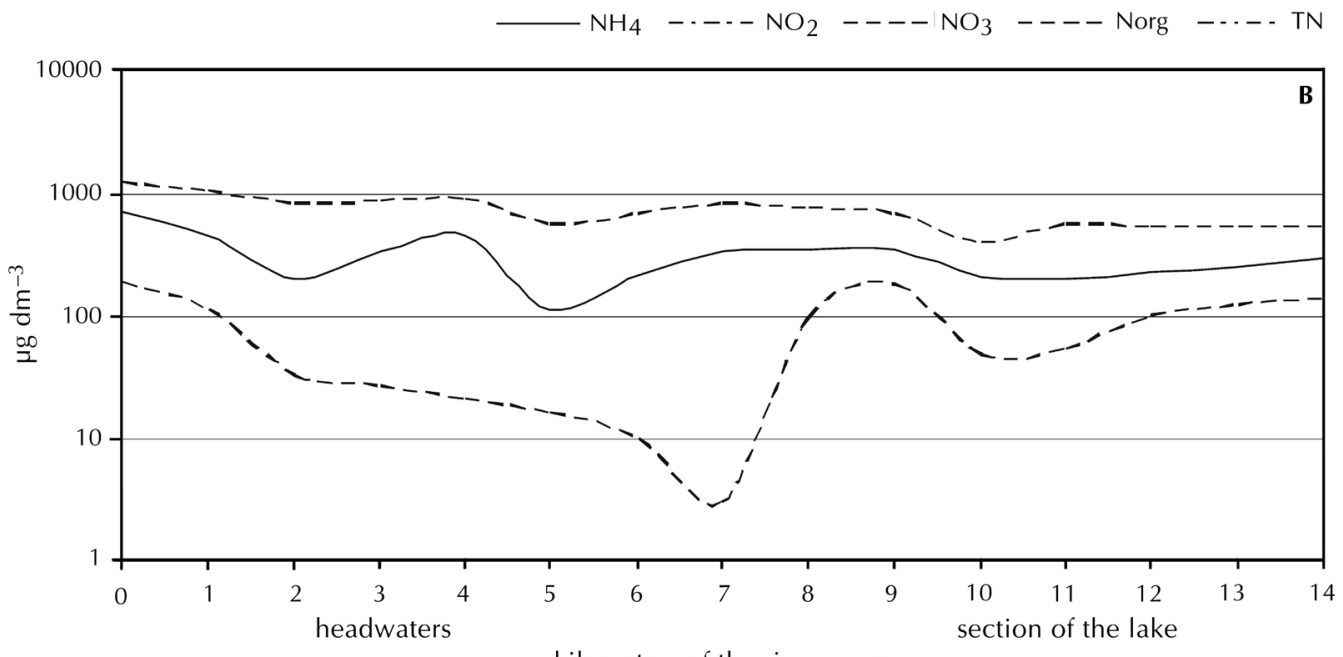

kilometres of the river course
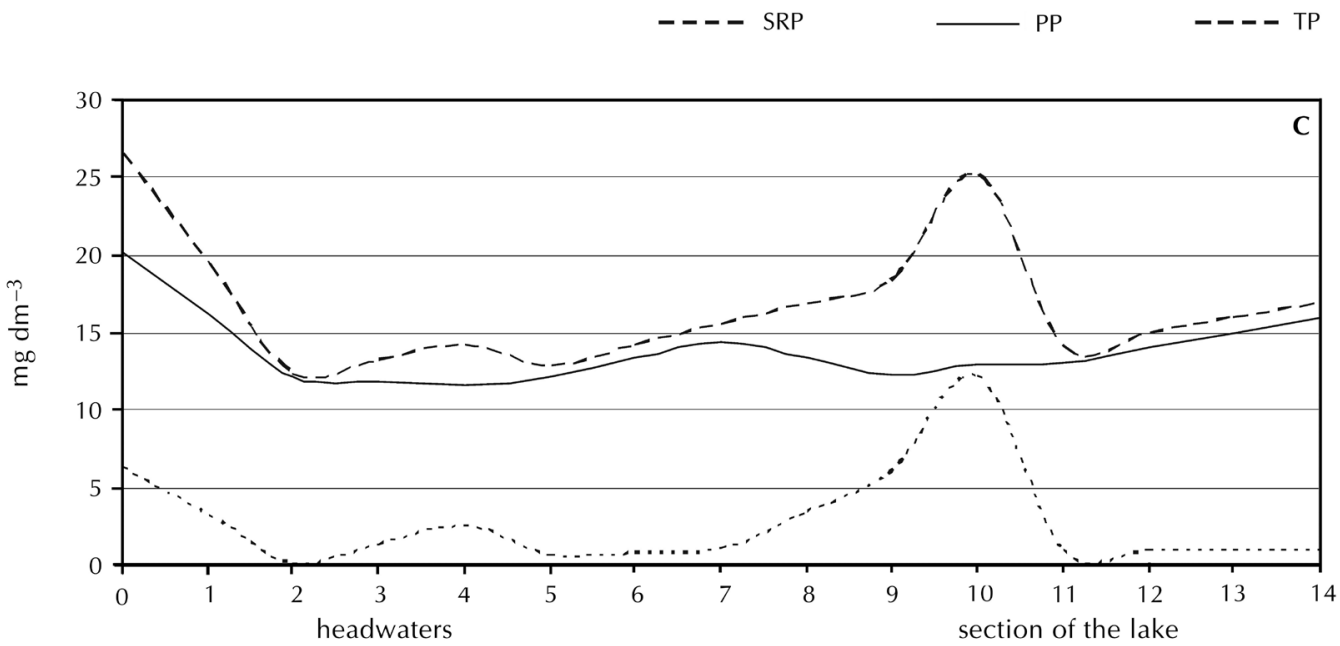

kilometres of the river course

Fig. 3. Changes in nutrient concentrations along the course of the Szeszupa River: A - nitrogen, B - phosphorus, C - organic carbon compounds 
er (Table 3). The Szurpiłówka and Jaczniówka River catchment plays an insignificant role in the transport of TP, and particularly of the organic fraction (Table $3)$. In the source section, SRP plays an insignificant role in the structure of total phosphorus, constituting only $5 \%$ of TP content. In the remaining partial catchments, the content of SRP is much higher, and amounts from 20 to $45 \%$. The highest amounts of DOC are supplied to the waters of the Szeszupa River from its direct catchment in the lake section $\left(161 \mathrm{mg} \mathrm{s}^{-1} \mathrm{~km}^{-2}\right.$ ) (Table 3), and the lowest from the Jaczniówka River catchment (25 mg s $\mathrm{mm}^{-1}$ ) (Table 3). The remaining catchments supply approximately half as much DOC. The main form of TOC in the fluvial water of the Szeszupa River catchment is DOC constituting more than $85 \%$ of TOC. Only in the lake section of the Szeszupa River does the content of DOC decrease to approximately $70 \%$.

Mesotrophic lakes include Lakes Perty and Jeglówek. Carlson's trophic state index of lakes through which the Szeszupa River flows oscillates around 60 (Table 2). The concentration and structure of biogenes in lakes of the SLP are varied. The highest amounts of biogene matter among all of the lakes studied are stored in large and deep lakes (Szurpiły, Kopane, Jaczno, Kameduł, and Jeglówek). Lake Szurpiły collects the highest loads of all the bioelements analysed except for the PP fraction, the highest amounts of which are accumulated in Lake Kopane $(961 \mathrm{~kg})$. The lowest amounts of biogene matter are accumulated in the small Lakes Postawelek and Kluczysko (Table 4).

\section{Discussion}

The water quality of rivers and lakes is determined by their geographical location, catchment management, quality of the inflowing waters, retention, land inclination, and mean depth of the water bodies. Human activity has a large impact on water quality (Bajkiewicz-Grabowska 2002; Ptak and Ławniczak 2012). In the SLP, anthropogenic transformations of the environment are still insignificant (Hillbrich-Ilkowska 1994, 2005). It is favoured by low population density in the area (population density of the Suwałki poviat is 28 people per $\mathrm{km}^{2}$ ) and the manner of its management. The basic direction of economic activity is ag-

Table 4. Loads $(\mathrm{kg})$ biogenic material stored in the lakes located in the Upper Szeszupa catchment

\begin{tabular}{|c|c|c|c|c|c|c|c|c|c|c|c|c|c|}
\hline \multirow{2}{*}{ Lake } & \multicolumn{5}{|c|}{ Nitrogen compounds } & \multicolumn{5}{|c|}{ Phosphorus compounds } & \multicolumn{3}{|c|}{ Organic carbon compounds } \\
\hline & $\mathrm{N}-\mathrm{NO}_{2}^{-}$ & $\mathrm{N}-\mathrm{NO}_{3}^{-}$ & $\mathrm{N}-\mathrm{NH}_{4}$ & TON & TN & SRP & ODP & DP & PP & TP & DOC & $\mathrm{POC}$ & TOC \\
\hline \multicolumn{14}{|c|}{ Szeszupa direct catchment } \\
\hline Linówek & 1 & 3 & 7 & 19 & 29 & 1 & 3 & 4 & 2 & 6 & 1304 & 219 & 1523 \\
\hline Gulbin & 2 & 14 & 75 & 197 & 287 & 6 & 35 & 40 & 13 & 53 & 2644 & 1104 & 3748 \\
\hline Okrągłe & 3 & 41 & 335 & 453 & 831 & 37 & 53 & 89 & 28 & 117 & 10178 & 1543 & 11721 \\
\hline Krajwelek & 3 & 26 & 251 & 484 & 763 & 9 & 48 & 56 & 26 & 83 & 6508 & 1977 & 8485 \\
\hline Przechodnie & 1 & 30 & 69 & 700 & 800 & 20 & 42 & 62 & 28 & 90 & 14620 & 2768 & 17388 \\
\hline Postawelek & 1 & 6 & 29 & 52 & 89 & 2 & 6 & 6 & 7 & 15 & 1235 & 41 & 1275 \\
\hline Kojle & 6 & 99 & 728 & 351 & 1291 & 16 & 220 & 236 & 109 & 345 & 15690 & 2381 & 18071 \\
\hline Perty & 7 & 77 & 133 & 796 & 1014 & 10 & 12 & 22 & 28 & 50 & 7232 & 812 & 8043 \\
\hline \multicolumn{14}{|c|}{ Jaczniówka catchment } \\
\hline Pogorzałek & 0,2 & 75 & 10 & 53 & 71 & 4 & 5 & 8 & 2 & 10 & 2224 & 194 & 2418 \\
\hline Jaczno & 12 & 173 & 1343 & 864 & 2391 & 156 & 559 & 715 & 149 & 864 & 35738 & 16070 & 51808 \\
\hline Kamenduł & 5 & 70 & 850 & 1014 & 1938 & 68 & 91 & 159 & 118 & 277 & 18729 & 1846 & 20576 \\
\hline \multicolumn{14}{|c|}{ Szurpiłówka catchment } \\
\hline Szurpiły & 26 & 720 & 2238 & 1110 & 4095 & 485 & 515 & 1000 & 549 & 1549 & 83427 & 12121 & 95545 \\
\hline Kluczysko & 1 & 12 & 73 & 24 & 110 & 5 & 15 & 20 & 16 & 36 & 3260 & 193 & 3453 \\
\hline Jeglóweczek & 0 & 3 & 7 & 20 & 30 & 1 & 1 & 2 & 4 & 6 & 1051 & 178 & 1229 \\
\hline Jeglówk & 11 & 69 & 215 & 747 & 1043 & 22 & 36 & 58 & 43 & 100 & 21944 & 8755 & 30700 \\
\hline Kopane & 6 & 107 & 87 & 1253 & 1452 & 12 & 28 & 40 & 961 & 1001 & 7784 & 434 & 8217 \\
\hline Udziejek & 1 & 13 & 77 & 63 & 154 & 9 & 35 & 44 & 7 & 51 & 2951 & 318 & 3269 \\
\hline
\end{tabular}


riculture, often ecological, and agrotourism. Increased agrotourism traffic is observed in summer, but it does not result in considerable environmental changes in the Szeszupa River catchment, including water eutrophication. The stability of certain water properties (e.g. Secchi visibility) of SLP lakes was mentioned by Hilbricht-Ilkowska and Wiśniewski (1994). A decrease in water transparency was only recorded in the lakes of the Szeszupa system. Current studies reveal relative stability of the feature, and the trophic state index calculated based on Secchi visibility in Lakes Gulbin, Okrągłe, Krajwelek, Przechodnie, and Postawelek oscillates around 50. In accordance with the suggestions of Hilbricht-Ilkowska and Wiśniewski (1994) as well as Górniak et al. (2007), TSI values calculated based on total phosphorus concentration significantly vary from the values calculated based on chlorophyll $a$ concentration and Secchi visibility. This suggests that the majority of limnic waters are currently mesotrophic or mesoeutrophic. In the lakes studied, high TP concentration does not significantly affect the development of phytoplankton, because the majority of TP is in an unavailable form. SRP in the waters of the lakes of the Szeszupa system often constitutes less than $20 \%$ of TP. Such a situation is probably related to the character of soils occurring in the catchments of lakes strongly sorbing phosphorus, making it unavailable for autotrophs (Hillbricht-Ilkowska 1994). The available phosphorus resources can also be restricted as a result of complexing by calcium, aluminium, and iron compounds which can be subject to sedimentation (Bigaj et al. 2012). Certain unfavourable symptoms of transformation of water quality in summer in the SLP were recorded in the Czarna Hańcza River catchment. Their manifestation is an increasing TSI value in Lake Hańcza (Jekatierynczuk et al. 2012).

The ecological state of waters of the Szeszupa River is estimated as moderate. Three of the lakes studied are classified to the very good ecological state. These are Lakes Linówek, Pogorzałek, and Perty. The remaining lakes are classified to the moderate ecological state due to high phosphorus concentrations.

The high quality of the aquatic environment is confirmed by the recorded concentrations of bioelements and their loads in lakes (Table 4). Loads of bioelements accumulated in lakes in the summer period are determined by the size of the lakes. The correlation coefficients calculated for water volume in a lake and accumulated load of biogenes usually exceed $0.90(\mathrm{p}<0.05)$. A somewhat lower correlation was de- termined between the volume of lakes and TON ( $\mathrm{r}$ $=0.63 ; \mathrm{p}<0.05$ ), and lack of correlation in the case of PP. Similar correlations were determined between the surface area of the lakes and the amount of accumulated loads of bioelements. This unequivocally suggests the lack of anthropogenic activity in the catchments or the very insignificant effect of it on the lakes' ecological and trophic state.

Transport of biogenic matter in waters is a very complex process. Bioelements are incorporated in the biological matter cycle, and are subject to various transformations along the river course, adopting both soluble and insoluble forms (Bajkiewicz-Grabowska 2002). In accordance with the river continuum concept (Vannote et al. 1990; Bretschko 1995), in the Szeszupa River, the following parameters change continuously from source to sink: channel width and depth, water velocity, water volume, and organic matter inflow. The river continuum concept assumes a decrease in biogene concentrations along the river course except for phosphorus, the concentrations of which should increase. In accordance with the above assumptions, in the Szeszupa River, a decrease in organic matter concentration occurs. Only TP concentration grows. The highest mean concentrations of this bioelement occur in the source section $\left(1.2 \pm 0.2 \mathrm{mg} \mathrm{dm}^{-3}\right)$. In the vegetation season 2009-2010, TP concentration in the water of sources of the Szeszupa River was still high - $0.78 \pm 0.43 \mathrm{mg} \mathrm{dm}^{-3}$. Similar values were recorded in the interstitial waters in the Szeszupa River valley floor in the source section $\left(0.78 \pm 0.35 \mathrm{mg} \mathrm{dm}^{-3}\right)$. The reason for the high TP concentration was the draining character of the river, and total precipitation in summer 2009-2010 being 25\% higher in relation to the multiannual level. Intensive precipitation increased surface runoff from the nearby cultivated land. This combined with a low discharge rate could reduce the amount of biogene compounds in the water of the Szeszupa sources. According to Miler (2002), the amount of phosphorus compounds depends on the oxygen content in water. In the Szeszupa River sources, one of the reasons for such a high amount of total phosphorus may be the low concentration of dissolved oxygen $\left(5.26 \pm 0.57 \mathrm{mg} \mathrm{O}_{2} \mathrm{dm}^{-3}\right)$. In the interstitial waters in the source part of the Szeszupa River valley, the mean oxygen concentration was even lower $(3.23 \pm 1.33 \mathrm{mg}$ $\mathrm{O}_{2} \mathrm{dm}^{-3}$ ). According to Bajkiewicz Grabowska (2002), in fluvial-limnic systems with deviations from the river continuum, transport and transformations of mineral materials are affected by the character of chemical 
compounds. In the source section of the river, macromolecular allochthonic organic matter occurs. Abundant grassy vegetation occurring there accumulates high amounts of nutrients inflowing from the catchment. A low discharge rate does not favour the fast transport of bioelements. On the contrary, it facilitates their accumulation. The source section of the Szeszupa River is located in the agricultural-forest part of the catchment, where cultivated land, meadows, and pastures constitute approximately $75 \%$ of the area of the partial catchment. Cattle breeding developing in the area, as well as considerable shortcomings in the storage of manure are the basic reason for the substantial transformation of groundwaters and disturbance of the river continuum.

The most important function in the migration of local agricultural pollutants is ascribed to ground outflow (Haag and Kaupenjohann 2001). This was confirmed in the source part of the Szeszupa River catchment. A significant role in the transport of dissolved compounds in water is played by surface runoff and shallow subsurface runoff (Banaszuk 2007), as well as natural and anthropogenic "surface hydrochemical corridors", including linear erosional forms, furrows, ruts, and ditch network (Haag and Kaupenjohann 2001). The occurrence of migration corridors may influence increased direct contact of the catchment with the river. Due to this, the migrating solutions can omit potential buffer structures securing surface waters against pollution (Krasowska and Banszuk 2011). It seems that in areas with high land denivelations, this phenomenon may be significant.

In Poland, the highest amount of nitrogen compounds supplied to groundwaters and surface waters comes from agriculture (Sapek and Sapek 2005). Soluble forms of nitrogen are transported with surface runoff (Kiryluk and Rauba 2009). In flowing waters of the Szeszupa River catchment, the predominating form of nitrogen was ammonia nitrogen, constituting $65 \%$ of TN. This suggests slow transformation of ammonia ions and continuous supply of pollutants from the catchment in the summer period. The predominance of $\mathrm{N}-\mathrm{NH}_{4}$ in the waters of the Szeszupa River may result from the application in fertilisation of high amounts of manure by local farmers. The field observations suggest intensive fertilisation of cultivated land in a natural manner. Continuous inflow of ammonia ions to water bodies also results from breeding of cattle remaining on pastures throughout the summer period, and grasslands usually located in the vicinity of rivers and lakes. Along $9 \mathrm{~km}$ of the river course, where the Szeszupa River flows out of Lake Gulbin, a decrease by 3-4 times in the concentration of $\mathrm{N}-\mathrm{NO}_{3}$ occurs. In the section where the Szeszupa River flows through Lakes Gulbin, Okrągłe, Krajwelek, Przechodnie, and Postawelek, the river valley is very wide, which favours strong growth of macrophytes. Little transformed anthropogenic lakes and forests in the functional-spatial structure of the catchment fulfil the function of biofilters of pollutants, and stabilisers of ecological conditions (Hilbricht-Ilkowska 2005; Bogdanowicz and Cysewski 2008). Along the river banks and around lakes, numerous forest assemblages occur. The littoral and rush vegetation, as a transitional zone between land and water, developing the waterland ecotone, constitutes a buffer for biogene compounds. Biophilic elements can be accumulated here and transformed together with autochthonic matter. Increased nutritive requirements of plants in the vegetation period result in a decrease in concentrations of forms of $\mathrm{N}-\mathrm{NO}_{3}$. The use of $\mathrm{N}-\mathrm{NO}_{3}$ in niches of lowland well-heads was experimentally evidenced by Jekatierynczuk-Rudczyk (2010).

Along with the growth of the catchment area, the Szeszupa River's channel expands and the discharge rate increases. Due to this, in spite of a decrease in the concentration of biogenes in water along the river course, the amount of transported biogenic matter increases. The effect of an increase in the discharge rate on the intensity of biogenic matter transport is confirmed by significant correlation coefficients ( $\mathrm{Ta}$ ble 5).

Water quality depends on processes occurring both in the catchment and in the river channel (Jekatierynczuk-Rudczyk et al. 2006; JekatierynczukRudczyk 2010). The lowest amounts of biogenic matter are supplied to the Szeszupa River from the most intensively forested Jaczniówka River catchment. Sim-

Table 5. Statistically significant correlations $(\mathrm{p}<0.05)$ between the load of transported nutrients and the flow rate along the course of the Szeszupa River

\begin{tabular}{lccccc}
\hline & $\mathrm{N}^{-\mathrm{NO}_{2}}{ }^{-}$ & $\mathrm{N}-\mathrm{NO}_{3}{ }^{-}$ & $\mathrm{SRP}$ & $\mathrm{DP}$ & $\mathrm{TP}$ \\
\hline Flow rate & 0.75 & 0.69 & 0.53 & 0.69 & 0.59 \\
\hline
\end{tabular}


ilar results were obtained in the Białystok region. The highest increase in the load of bioelements in the waters of the Szeszupa River was recorded in the vicinity of the Udziejek village, where the river flows into a regulated channel. Intensive inflow of biogenic matter from meliorated areas occurs here. Meliorated areas can transport particularly high amounts of biogenes. In the vicinity of Lake Okragłe, the largest source of pollutants is located, namely numerous outlets of melioration ditches draining water from cultivated land located in the direct vicinity of the lake, and forest complexes located at a somewhat larger distance. Here, the amount of transported biogenic compounds in the waters of the Szeszupa River reaches its maximum, and increases twofold in relation to the upper course of the river. In the Szurpiłówka River catchment, in spite of the prevalence of agricultural land, an insignificant load of nitrogen and phosphorus occurs. In the case of TON and TN, elementary runoff is lower than that in the more forested Jaczniówka River catchment. This results from the bioaccumulation of biogenes in flow-through lakes (Bajkiewicz-Grabowska 2002; Lossow et al. 2006; Maślanka and Jańczak 2010). In fluvial-limnic systems, lakes constitute an element disturbing the river continuum. They change the outflow conditions and load of matter transported by the river. In lakes, accumulation of matter both supplied from the catchment and produced in the catchment occurs. They fulfil the function of a kind of "collector" of matter and sediments, and their stability is determined by hydrological conditions (Wetzel 2001). The greater the depth of a lake, the higher their water retention capacity, and the more effect it has on the modification of the fluvial outflow (BajkiewiczGrabowska 2002).

The transformation of the original landscape into an agricultural landscape results in a change in water relations in the area. This affects the small water circulation, causing its shortening and simplification. This, in turn, reduces water retention in soils, worsens the infiltration conditions, and facilitates surface runoff of precipitation waters (Stachowicz 1995). Higher concentrations of dissolved organic carbon in the rivers of the Szeszupa River catchment may result from the fact that meadow ecosystems can annually produce the amount of biomass similar to that produced by forest ecosystems (Jekatierynczuk-Rudczyk et al. 2006). The mean DOC concentration in the waters of the Szeszupa River amounts to $13.9 \mathrm{mg} \mathrm{dm}^{-3}$, and constitutes almost the entire total organic carbon. The low proportion of POC (16.5\% on average) in total organic carbon was observed in numerous studies (Wetzel 2001; Parks and Baker 1997; Suchowolec and Górniak 2006).

\section{Conclusion}

1. Transport of biogenes along the course of the Szeszupa River occurs in accordance with the river continuum concept with the exception of TP. TP concentrations increase along the river course.

2. The increased proportion of forests in the Jaczniówka River catchment clearly decreases the number of biogenes in the river. The remaining partial catchments with a higher proportion of cultivated land, meadows, and pastures supply higher amounts of bioelements to the main river.

3. The hydrochemical state of the Szeszupa River is moderate due to the increased concentrations of total phosphorus and total organic carbon. Lakes Linówek, Pogorzałek, and Perty have a very good ecological state. The remaining lakes, due to increased phosphorus concentration, belong to the group with a moderate ecological state.

4. Loads of bioelements accumulated in lakes in the summer period are determined by the size of the lakes.

\section{Acknowledgements}

The study was supported by the Ministry of Science and Higher Education (MNiSW) under project number N N306 275135.

\section{References}

Bajkiewicz-Grabowska E., 1994, Charakterystyka fizycznogeograficzna i hydrograficzna Suwalskiego Parku Krajobrazowego (Physico-geographical and hydrographical characteristics of Suwałki Landscape Park), [in:] Hillbricht-Ilkowska A., Wiśniewski R.J. (eds) Jeziora Suwalskiego Parku Krajobrazowego. Związki z krajobrazem, stan eutrofizacji i kierunki ochrony (Lakes of the Suwałki Landscape Park. Links with landscape, eutrophication and protection measures), Zesz. Nauk. Kom. Nauk. PAN „Człowiek i Środowisko” 7: 15-31 (in Polish, English summary).

Bajkiewicz-Grabowska E., 2002, Obieg materii w ekosystemach rzeczno-jeziornych (Circulation of matter in river-lake systems), Wyd. UW, Warszawa, p. 274 (in Polish, English summary). 
Banaszuk P., 2007, Wodna migracja składników rozpuszczonych do wód powierzchniowych w zlewni górnej Narwi (Water-soluble components migrate to the surface water in the basin of the upper Narew), Wyd. PBiał., Białystok, p. 182 (in Polish).

Bigaj I., Łopata M., Dunalska J., Szymański D., Zieliński R., 2012, Bottom sediments as a potential source of phosphorus in the riverine-lacustrine system of the Kośna River (Northeastern Poland), Limnol. Rev. 12(3): 115-124.

Bogdanowicz R., Cysewski A., 2008, Transformation of riverine nutrients load in selected lakes of the Zaborski Landscape Park, Limnol. Rev. 8(1-2): 13-19.

Bretschko G., 1995, River/land ecotones: scales and patterns, Hydrobiologia 303: 83-91.

Carlson, R. E., 1977, A trophic state index for lakes, Limnol. Oceanogr. 22: 361-369.

Górniak A., 2000, Klimat województwa podlaskiego (Climate of Podlaskie Voivodeship), IMGW, Białystok, p. 119 (in Polish).

Górniak A., Szumieluk D., Zieliński P., Suchowolec T., Jekatierynczuk-Rudczyk E., 2007, Jeziora Suwalskiego Parku Krajobrazowego - aktualna trofia i jakość wód (Lakes in the Suwalki Landscape Park - current trophy and water quality), [in:] XXX lat Suwalskiego Parku Krajobrazowego (30 years of the Suwałki Landscape Park), Stow. Miłośników SPK „Kraina Hańczy”, Malesowizna-Turtul: 31-36 (in Polish).

Haag D., Kaupenjohann M., 2001, Landscape fate of nitrate fluxes and emissions in Central Europe. A critical review of concepts, data, and models for transport and retention, Agr. Ecosyst. Environ. 86: 1-21.

Hermanowicz W., Dojlido J., Dożańska W., Koziorowski B., Zerbe J., 1999, Fizyczno-chemiczne badanie wody i ścieków (Physical-chemical examination of water and wastewater), Arkady, Warszawa, p. 556 (in Polish).

Hillbricht-Ilkowska A., 1994, Ocena ładunku fosforu i stanu zagrożenia jezior Suwalskiego Parku Krajobrazowego oraz niektóre zależności pomiędzy ładunkiem a wskaźnikiem trofii jezior (Evaluation of the phosphorus load and degree of endangerment, of lakes in Suwałki Landscape Park, and some relationhips between the load and the indices of the status of lakes), [in:] Hillbricht-Ilkowska A., Wiśniewski R.J. (eds) Jeziora Suwalskiego Parku Krajobrazowego. Związki z krajobrazem, stan eutrofizacji i kierunki ochrony (Lakes of the Suwałki Landscape Park. Links with landscape, eutrophication and protection measures), Zesz. Nauk. Kom. Nauk. PAN „Człowiek i Środowisko” 7: 201-214 (in Polish, English summary).

Hillbricht-Ilkowska A., 1999, Shallow lakes in lowland river systems: Role in transport and transformation of nutrients and in biological diversity, Hydrobiologia 408/409: 349-358.

Hillbricht-Ilkowska A., 2005, Ochrona jezior i krajobrazu pojeziernego - problem, procesy, perspektywy (Protection of lakes and lakelands - problems, processes, perspectives), Kosmos 54: 285-302 (in Polish).
Hillbricht-Ilkowska A., Wiśniewski A., 1994, Zróżnicowanie troficzne jezior Suwalskiego Parku Krajobrazowego i jego otuliny. Stan obecny, zmienność wieloletnia, miejsce w klasyfikacji troficznej jezior (Trophic diversity of the lakes of SLP and its buffer zone, current state, longterm variability and place in the trophic classification of lakes), [in:] Hillbricht-Ilkowska A., Wiśniewski R.J. (eds) Jeziora Suwalskiego Parku Krajobrazowego. Związki z krajobrazem, stan eutrofizacji i kierunki ochrony (Lakes of the Suwałki landscape Park. Links with landscape, eutrophication and protection measures), Zesz. Nauk. Kom. Nauk. PAN „Człowiek i Środowisko” 7: 181-200 (in Polish, English summary).

Jańczak J., 1999, Atlas jezior Polski. Jeziora Pojezierza Mazurskiego i Polski południowej (The Atlas of Polish lakes. Lake of the Mazury Lake District and the southern Poland), IMGW, Poznań, p. 240 (in Polish).

Jekatierynczuk-Rudczyk E., 2010, Przekształcenie składu fizyczno-chemicznego płytkich wód podziemnych w strefach drenażu na obszarach nizinnych (Transformation in physico-chemical composition of groundwaters within lowland drainage zones), Wyd. UwB, Białystok, p. 224 (in Polish, English sumary).

Jekatierynczuk-Rudczyk E., Zieliński P., Górniak A., 2006, Stopień degradacji rzeki wiejskiej w bezpośrednim sąsiedztwie Białegostoku (Degradation of a rural river in the close vicinity of Białystok), Woda Środ. Obsz. Wiej. 6(2): 143-153 (in Polish, English summary).

Jekatierynczuk-Rudczyk E., Grabowska M., Ejsmont-Karabin J., Karpowicz M., 2012, Assessment of trophic state of four lakes in the Suwałki Landscape Park (NE Poland) based on the summer phyto- and zooplankton in comparison with some physicochemical parameters, [in:] Wołowski K., Kaczmarska I., Ehrman J., Wojtal A.Z. (eds), Phycological Reports: Current advances in algal taxonomy and its applications: phylogenetic, ecological and applied perspective, Inst. Botaniki PAN, Kraków: 205-225.

Kiryluk A., Rauba M., 2009, Zmienność stężenia związków azotu w różnie użytkowanej zlewni rolniczej rzeki Ślina (Variability of nitrogen concentrations in the variously used agricultural catchment of the Slina River), Woda Środ. Obsz. Wiej. 9(4): 71-86 (in Polish, English summary).

Kondracki J., 1998, Geografia regionalna Polski (Regional geography of Poland), Wyd. PWN, Warszawa, p. 441 (in Polish).

Krasowska M., Banaszuk P., 2011, Wymywanie składników rozpuszczonych w małej zlewni rolniczej podczas wezbrania roztopowego (Leaching of dissolved components from a small agricultural catchment during a snowmelt induced high flow event), Woda Środ. Obsz. Wiej. 11(1): 139-157 (in Polish, English summary).

Lossow K., Gawrońska H., Łopata M., Teodorowicz M., 2006, Role of lake in phosphorus and nitrogen transfer in the river-lake system of the Marózka and the upper Łyna rivers, Limnol. Rev. 6: 171-178. 
Maślanka W., Jańczak J., 2010, Circulation of biogenic substances in the Kamionka river-lake system, Limnol. Rev. 10(2): 95-105.

Miler A. T. 2002, Skład chemiczny oraz unosiny i zawiesiny w ciekach dwóch mikrozlewni o kontrastowym zalesieniu (The chemical composition and suspension in streams of two microbasins with contrasting afforestation), Prz. Nauk. Wydz. Inż. Kształt. Środ. 11(2): 62-70 (in Polish, English summary).

Nowakowski C., 1976, Charakterystyka wydajności źródeł strefy czołowomorenowej Pojezierza Suwalskiego (Characteristics of the capacity of springs in the frontal moraine zone in Suwalki Lake District), Biul. Geol. Wydz. Geol. UW 21: 177-191 (in Polish).

Parks S.J., Baker L.A., 1997, Sources and transport of organic carbon in an Arizona river-reservoir system, Wat. Res. 31(7): 1751-1759.

[PIG] Państwowy Instytut Geologiczny, 2009, Mapa Hydrogeologiczna Polski w skali 1:50 000, arkusz Jeleniewo (Hydrogeological Map of Poland at the scale 1:50 000, sheet Jeleniewo), PIG, Warszawa.

Ptak M., Ławniczak A. E., 2012, Changes in land use in the buffer zone of lake of the Mała Wełna catchment, Limnol. Rev. 12(1): 35-44.
Sapek A., Sapek B., 2005, Strategia gospodarowania azotem i fosforem w rolnictwie w aspekcie ochrony wód Morza Bałtyckiego (Strategy management of nitrogen and phosphorus in agriculture in terms of the protection of the Baltic Sea), Zesz. Edukac. IMUZ 10: 23-27 (in Polish).

Suchowolec T., Górniak A., 2006, Sezonowość jakości wody małych zbiorników retencyjnych w krajobrazie rolniczym Podlasia (Seasonal changes of water quality in small reservoirs in the agricultural catchment of Podlasie), Woda Środ. Obsz. Wiej. 6(2): 347-358 (in Polish, English summary).

Stachowicz K., 1995, Migracja wodna składników pokarmowych ze zlewni rolniczych (Water migration of nutrients from agricultural catchments), Człow. Środ. 19(1): 125-141 (in Polish).

Vannote R.L., Minshall G.W., Cumming K.W., Sedell J.R., Cushing C.E., 1980, The river continuum concept, Can. J. Fish. Aquat. Sci. 37: 130-137.

Wetzel R.G., 2001, Limnology. Lake and river ecosystems, Academic Press, San Diego, p. 1006. 